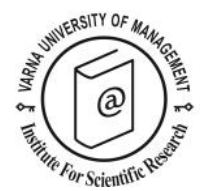

\title{
Walia, S.K. (ed.) (2021). The Routledge Handbook of Community- Based Tourism Management: Concepts, Issues and Implications. Routledge: New York \& London. ISBN 978-0-367-22391-5, 529 pp.
}

\author{
Reviewed by \\ Sagar Singh ${ }^{1 *}$
}

\begin{abstract}
${ }^{1}$ Centre for Tourism Research and Development, Lucknow, India. E-mail: sagar_66@hotmail.com
${ }^{*}$ Corresponding author
\end{abstract}

Citation: Singh, S. (2022). Book review of Walia, S.K. (ed.) (2021). The Routledge Handbook of Community-Based Tourism Management: Concepts, Issues and Implications. ISBN 978-0-367-22391-5, Routledge: New York \& London. European Journal of Tourism Research 30, 3018. 
The book is a very extensive look at community-based tourism (CBT) management from various angles. Divided into five parts, this edited volume, like all handbooks, seeks to cover all possible aspects of the problematic: in this case, how communities can act as enterprises and cooperatives that can allow maximization of not only profits but also socially useful ways in which tourism can benefit host communities, especially rural ones. The book has 40 chapters in 5 sections, which includes an 'Introductory part' with 9 chapters, with a "preamble"; a chapter on "harmonic methodology" planning of CBT; an overview that covers histories as well as an evaluation framework on CBT management (by Yusuke Ishihara); and six more chapters, including case studies of El Cisne in Ecuador; Alentejo, Portugal; and Pichilemu, Chile. The book is noteworthy for covering areas that are often neglected in the tourism literature, ranging from Brazil, Chile, Ecuador, Mexico and Panama in South/Central America, to Trinidad in the Caribbean; Spain, Portugal, Italy and Sweden in Europe; as also India, Indonesia, Nepal, Thailand and Turkey in Asia; and Kenya, Tanzania and Uganda in Africa. Part 2 consists of seven chapters devoted to Turkey, Ecuador, Indonesia, Italy, Mexico and Sweden, etc.

Part 3 has 9 chapters, that take up Ecuador, Nepal, Mexico, Tanzania, Turkey; and an insightful Chapter 23 on 'Social media and destination development', besides a chapter on CBT in Africa (Chapter 24 on Uganda and Kenya); and a pertinent analysis of community-related corporate social responsibility in the hotel sector. Section 4 is on 'Paradoxes of CBT', which consists of 5 chapters, including on women travellers in India; a highly interesting study of the role of children and resort mini-clubs in CBT (by Hugues Séraphin and Maximiliano Korstanje); a case study on 'Saving the leatherback turtle in the Grand Riviere, Trinidad'; a chapter on overtourism in communities; and one on 'rethinking CBT in response to climate change', that rounds off this section well.

Part 5 has 10 chapters on the 'future of CBT'. These range from 'community-based events and social entrepreneurship' in Italy; bikes and trans-boundary tourism in the Republic of Montenegro; a chapter on rural tourism in Asia; one on sustainable CBT in Thailand (Chapter 32); another on indigenous tourism in Panama (Chapter 33); a general chapter on engagements with indigenous communities through tourism by Puvaneswaran Kunasekaran and Jeetesh Kumar (Chapter 38); and another general chapter on CBT in emerging economies by Toney Thomas; besides a concluding chapter by the editor and another author.

The book is a valuable addition to the literature and a wide span. However, tribal communities, which are analytically distinct, are not differentiated from farming rural communities with regard to CBT. Again, as tourism has for long been considered an alternative by urban communities for economic development or regeneration (for example, in Scotland), the conceptual emphases in rural and urban community management surely differ. While these points have been covered in the book (e.g., Chapters $32,33,38)$, editorial analysis of these aspects is missing. While not negating the value of the book, the last point is important from the viewpoint of students who are beginners or even advanced researchers in tourism management. The "preamble to the literature" in Part 1 fails to provide a clear solution to the problem of how to weed out the negatives of tourism development that a community faces while enhancing the positive impacts. The editor talks about social exchange theory, but the notion of "trading" of benefits versus costs, rules out a deeper structural analysis of how deep-seated schisms in communities, along class and power lines, make the concept of an "all-beneficial CBT" a troubled hypothesis. This needs to be argued for and against; but that is, unfortunately, not done.

The division of the book into five parts makes for easier reading, but the placement of many chapters is sometimes troublesome. The placing of some chapters in Part 1, while providing valuable insights on culturally-specific reactions to community "development" through tourism, could as easily have been 
placed in Part 2. The second part has two short chapters both of which could fit in Part 1: especially Chapter 16, 'The role of community-based tourism initiatives in socio-economic development', by Eva Maria Jernsand and Helena Kraff. This otherwise thought-provoking book sometimes lacks clarity on the location of communities, taken up in various chapters, in introductory passages or chapter titles. For example, it takes some reading to know where El Cisne is located (in Chapter 7), or where is Pichilemu (Chapter 9). Again, in Part 3, Chapter 21, it is difficult to place in which country is Saadani National Park located (Tanzania is mentioned after many pages of discussion).

Some chapters in Part 3, which seems, on the face of it, to cover the whole book, are insightful general write-ups, such as Chapter 18, on 'Tourist guides' roles and responsibilities in community-based tourism approach', by Gül Erkol Bayram; and Chapter 19, 'Community-based homestay tourism and social inclusion' by Kishor Chitrakar, Neil Carr and Julia Albrecht. These should be rightfully treated as introductions to the question of social and financial inclusion and tourism with reference to CBT. However, this also highlights the lack of emphasis in the book on the theme of community-based tourism and poverty reduction, which is especially important, given the current scenario of coronavirus disease (COVID) and drastic drops in both domestic and international tourist arrivals in 2020, the latter by over 70\% (one billion) over the previous assessed year (2019), according to UNWTO (2021).

The book also misses out on wider coverage of communities in developed nations in regions like West Europe (example, France and UK), Central Europe (Germany), Eastern Europe, Russia; and North America, besides Australia, New Zealand, and China. While it is difficult and not profitable to generalize about communities as a whole in these world regions, their inclusion could have helped see how capitalism-driven economies fare versus communist or socialist-oriented economies, to draw valuable lessons on CBT management. Moreover, relative poverty exists even in developed or centrallyadministered economies. In these economically lean times, such case studies could have helped gain perspectives on what is best practice and how communities develop core competence in managing tourism so that it benefits communities more than it endangers their existence.

Overall, this is a useful book, suitably illustrated with quite some graphs and diagrams, as well as photographs and tables. Thick as it is, its rich knowledge should make it a handy guide in libraries where new students of tourism and mobility learn about cultural and civilizational differences in CBT management, the various shades of community-driven planning versus top-down or government-led approaches that were, sometimes still are, popular when handling tourism as a tool for economic development. Some of its regional coverage - for example, countries of South America and Africa, that are under-represented in the tourism literature - speaks for its usefulness for students, researchers and teachers, besides practitioners and country managers who want to learn how to utilise tourism for greater community benefits.

\section{Reference}

UNWTO (United Nations World Tourism Organisation) (2021). 2020: Worst year in tourism history with 1 billion fewer international arrivals. Retrieved from: https://www.unwto.org/news/2020-worstyear-in-tourism-history-with-1-billion-fewer-international-arrivals (Accessed on 2.2.2021)

Received: 24/02/2021

Accepted: 28/02/2021

Coordinating editor: Stanislav Ivanov 